jects exclusively connected with railways, no account of them is given. (3) Industrial schools with a course of general education not exceeding the scope of the course of primary schools, or sometimes reaching the standard of the second class in village schools with two clasees. In most of them pupils are received who have completed the course in the public school, and who repeat what they have gone through in it. These schools are founded with the object of preparing skilled artisans for village and domestic industries, and also factory hands. They contain workshops for joiners, blacksmiths, carpenters, fitters, tailors, shoemakers, saddlers, bookbinders, \&c. ; but few of these institutions can boast of a systematic course of instruction in trades. (4) To this group belong various special and general educational schools for adults, as the school for foremen builders, the school for printers, the evening and Sunday special classes of the Imperial Technical Society at St. Petersburg, the Riga Industrial School, \&c. The teaching in these institutions takes place in the evenings of week-days, and on Sundays, i.e. when the adult workmen for whom they are intended are free from their work. (5) This group consists of elementary schools of general education, i.e. primary, district, or municipal schools with supplementary industrial sections. It is worthy of notice that persons who have gone through the whole course, or at least reached a certain standard, at any of the schools of these five groups, enjoy certain privileges with regard to exemption from military service.

The report then goes on to describe in detail the courses of some of the leading industrial schools as types of the different groups, as well as of the industrial classes attached to the elementary schools. In conclusion, the report summarizes the more important provisions of the ukase of March $7 / 19,1888$, respecting the conditions under which technical and industrial schools may be opened in Russia, either wholly or in part, at the expense of the State (given in Appendices I., II., III.). The cost of maintenance of these schools is respectively estimated in the ukase as follows: the intermediate mechanical technical schools at 27,3IIr. (£2730) per annum; the elementary mechanical technical schools at I9,436r. ( $(1945)$ per annum; and the trade schools at II,96or. (£I200) per annum. The Ministry of Education has assigned for this year the sum of $f 50,003$ for the creation of these technical schools, and it is reported that the Ministry has been urged to devote a considerable portion of this sum to founding schools in the districts where village industries prevail, the richer manufacturing districts being better able to dispense with State aid. The provisions of the ukase are:-(I) The industrial schools for the male inhabitants of the Empire exist for the purpose of diffusing among the population technical education of the intermediate and elementary standards, as well as instruction in handicrafts. (2) The intermediate technical schools impart the instruction and skill indispensable to artificers who are destined in time to act as the trusted assistants of engineers and of other managers of industrial enterprises. (3) The elementary technical schools, besides initiation into the mysteries and methods of some one definite handicraft, likewise impart the knowledge and skill indispensable to men whose duty it will in time become to act as master-workers and immediate overseers of the operations of artisans in industrial establishments. (4) The trade schools exist for the purpose of giving practical tuition in the methods of any one trade, and at the same time of communicating such knowledge and skill as are absolutely necessary to the intelligent execution of the work of such trade. (5) Industrial schools of each of the above-mentioned categories can exist either apart or in conjunction with other similar schools of various degrees and specialities. (7) The industrial schools are supported at the expense of the Crown, or of the zemstvos, societies, guilds, or private individuals, or by funds contributed simultaneously from all these sources. (8) The course in the intermediate technical schools is not to exceed four years ; that of the elementary and trade schools three years. (9) Those who enter trade schools are required to produce a certificate of their having gone through the course of an elementary school ; those who enter the elementary technical schools, a certificate of having gone through the course in a municipal school, or village school, with two classes; while those who enter intermediate technical schools must have gone through five classes of a Realschule. (10) Those who are unable to satisfy the conditions mentioned in the preceding paragraph, but who have worked not less than two years in industrial institutions, and have proved that they can successfully follow the course at the school they wish to enter, may be also admitted. (iI) Industrial schools must have : (a) a library, (b) a room with appliances for geometrical and freehand drawing, $(c)$ where possible a room with appliances for modelling, $(d)$ the necessary school books for the special object for which the school is intended, and in addition the requisite appliances for the practical work of the apprentices. (14) Pupils who have successfully completed their education in an intermediate technical school, after a four years' course, receive the appellation of artificer in their specific calling. Those who have only gone through a two or three years' course, only receive this appellation after three or two years respectively, spent uninterruptedly in industrial work. Those who are so styled obtain certain privileges as regards their civil status and in respect to military service, and they enjoy in addition the right of entering the higher technical schools. Those who have completed the course at the other two categories of schools enjoy the privileges as regards civil status and military service which correspond to the general education they have received.

\section{FOSSIL FISH OF THE SCANDINAVIAN CHALK.}

MR. DAVIS has availed himself of the opportunities presented to him by the chief officers of the Museums of Lund, Stockholm, and Copenhagen, and has published a monographic account of the fish remains from the Cretaceous formations of Scandinavia.

Over seventy years ago Sven Nillson first discovered fish remains in the Swedish chalk. Since then numerous large collections have been made by the officers of the Geological Survey of Sweden and others, and the greater number of these specimens were unreservedly placed at the disposal of $\mathrm{Mr}$. Davis for description in his memoir; he has also had the opportunity of consulting some smaller collections in Sweden, and most of the forms have been figured from the original specimens by Mr. Crowther.

These fish remains show a closer relationship to the Cretaceous fish remains of the north of Europe, as represented by the English and French chalk fish, than to the more highly specialized chalk fauna of Asia Minor, but they do not afford representatives of several of the Physostomous Teleosteans, such as Ichthyodectes, Protosphyræna, and Pachyrhizodus, which have been found in the Einglish chalk, and have also occurred in the Upper Cretaceous rocks of North America.

The great majority of the fish remains are Selachian, and comprise twenty-four species. Of these, Carcharodon rondeletii, Otodus obliquus, and Odontaspis acutissimus are regarded as indicating a Tertiary fauna, but in the Scandinavian chalk they have been found asoociated with many undoubted Cretaceous forms in the Faxe limestone or chalk. The character and extent of this fauna indicates conditions very similar to those accompanying the deposition of the English and French chalk and of that of Central Europe generally, whilst it affords comparatively few data for comparison with that of Lebanon. The occurrence of numerous teeth of several species of Scapanorhynchus in the Swedish area is worthy of note, but the fish are not found preserved bodily as they are in the chalk of Lebanon.

This memoir is published as Part vi. of vol. iv. of the Transactions of the Royal Dublin Society, and is illustrated with an atlas of nine plates.

\section{SOCIETIES AND ACADEMIES. \\ LONDON.}

Royal Society, May 28.- "On the Bases (Organic) in the Juice of Flesh. Part I." By George Stillingfleet Johnson, M.R.C.S., F.C.S., F.I.C. Communicated by Prof. G. Johnson, F.R.S.

The author has endeavoured to ascertain by careful experiments how far the substances hitherto prepared from flesh are true "educts," and really present in the flesh itself, or merely pro. ducts, due to (I) the action of chemical or physical agencies applied in the course of extraction, or (2) to bacterial action modifying the composition of the flesh before it comes into the hands of the operator.

The final conclusion drawn is that sarcous kreatine is not present in fresh muscle, but results from bacterial action whereas sarcous kreatinin is probably a true "educt." 